\title{
"Apacin" Learning Model in Writing Poetry for Elementary School
}

\section{Henny Dewi Koeswanti ${ }^{*}$}

\author{
${ }^{1}$ Universitas Kristen Satya Wacana, Salatiga, Indonesia
}

\section{ARTICLE INFO}

\section{Article history:}

Received September 22, 2021

Revised September 29, 2021

Accepted October 22, 2021

Available online November 25, 2021

\section{Kata Kunci:}

Model Pembelajaran, Sekolah Dasar APACIN

Keywords:

Learning Model, Elementary School, APACIN

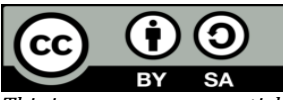

This is an open access article under the $C C$ BY-SA license.

Copyright (c) 2021 by Author. Published by Universitas Pendidikan Ganesha.

\begin{abstract}
A B S T R A K
Siswa kesulitan dalam memahami materi pembelajaran, sehingga berdampak pada kemampuan siswa yang rendah. Hal ini akan berdampak pada hasil belajar siswa yang rendah. Banyak factor yang menyebabkan siswa kesulitan dalam memahami materi pembelajaran. Salah satu factor yang mempengaruhi yaitu model pembelajaran. Tujuan penelitian ini yaitu menghasilkan sebuah pengembangan model pembelajaran baru yang bernama APACIN yang meruakan akronim dari sintak pembelajaran Amati, Pikir, Analisis, Cipta, dan Informasi. Metode yang digunakan dalam penelitian ini yakni deskriptif kualitatif dengan pendekatan studi kasus pada siswa sekolah dasar. Hasil penelitian ini yakni model pembelajaran APACIN mampu memberikan alternatif solusi atas permasalahan pembelajaran yang dihadapi oleh guru dan siswa. Melalui model pembelajaran APACIN ini, guru dan siswa lebih bisa berinteraksi serta siswa secara individu dan kelompok mampu memberikan solusi-solusi atas permasalahan kontekstual yang dibahas dalam pembelajaran. Di samping itu penerapan model pembelajaran APACIN dapat membangun berpikir kritis, berpikir kreatif, berpikir reflektif, dan pengambilan keputusan pada siswa. Model pembelajaran APACIN akan memudahkan siswa dalam belajar sehingga akan berdampak pada hasil belajar siswa yang meningkat.
\end{abstract}

\section{A B S T R A C T}

Students have difficulty understanding the learning material, which has an impact on students' low abilities. It will have an impact on low student learning outcomes. Many factors cause students difficulty in understanding the learning material. One of the influencing factors is the learning model. This research aims to produce a new learning model development called APACIN, an acronym for the learning syntax Observe, Think, Analyze, Create, and Information. The method used in this research is descriptive qualitative with a case study approach to elementary school students. The result of this study is that the APACIN learning model can provide alternative solutions to learning problems faced by teachers and students. Through this APACIN learning model, teachers and students can interact more, and students individually and in groups can provide solutions to contextual problems discussed in learning. In addition, the application of the APACIN learning model can build critical thinking, creative thinking, reflective thinking, and decision making in students. The APACIN learning model will make it easier for students to learn so that it will impact increasing student learning outcomes.

\section{INTRODUCTION}

Efforts to improve the quality of education starting from the basic level should be carried out continuously and consistently. It can be done by understanding the concept of curriculum contextually in order to implement the curriculum in the learning model and placing students as learning subjects (Daunic et al., 2021; Sutrisno et al., 2021; Wulandari, 2020). The learning must also be adjusted to the standardization of the development of student abilities (Dhiu, 2017; Prayekti, 2018; Zeptyani \& Wiarta, 2020). Students at the elementary level generally have a high curiosity and like to interact and cooperate with other students (Kusmariyatni, 2020; Septianti \& Afiani, 2020). The paradigm of a child will usually be to spend most of the time involved in various activities and cooperating with other children. These activities must be used as opportunities in educational activities for elementary school students. Quality improvement can be made by learning that can optimize the potential of students individually or in groups in interacting, innovating, and solving a problem comprehensively (Anggreni et al., 2020; Kurnia et al., 2019; Sari et al., 2017). The problem that occurs today is that many students still do not understand the learning material delivered by the teacher (Arthaningsih \& Diputra, 2018; Dewi et al., 2019; Setianingsih et al., 2019). Students have difficulty understanding learning materials so that it has an impact on students' low abilities (Arisantiani et al., 2017; Pramana \& Suarjana, 2019; Widani et al., 2019). It will have an impact on low 
student learning outcomes. Many factors cause students difficulty in understanding the learning material. One of the influencing factors is the learning model. Inappropriate learning models make students bored quickly in learning (Handayani et al., 2017; Lestari et al., 2017). The monotonous learning model used in learning makes it difficult to understand learning material because students feel sleepy quickly (Ayuni et al., 2017; Santiasih et al., 2013; Seika Ayuni et al., 2017). If this is allowed, elementary school students do not have good quality.

Learning for elementary school students is an important educational activity to prepare for a quality generation. Learning for elementary school students refers to a thematic and integrative learning program according to the needs of each class (Bahtiar, 2019; Kusmariyatni, 2020; Septianti \& Afiani, 2020). In this era, the learning paradigm leads to developing student competencies by optimizing patterns of critical thinking, communication, collaboration, creative thinking, and innovation (Permatasari et al., 2021; Widodo, 2014). Critical thinking is the main foundation for students to be sensitive in dealing with situations and conditions or problems around them (Mahmuzah, 2015; Suparni, 2016). Communication means that students must be able to communicate ideas, ideas, and the results of their identification to be conveyed to other parties regarding collaboration. It is intended to maximize the potential of each student so that they can solve problems by strengthening collaboration and coordination comprehensively according to their abilities. Creative thinking must also be emphasized to students so that they dare to come up with ideas based on the collaboration results and the originality of their thoughts (Marliani, 2015; Suherti \& Tsuroya, 2019).

Ideally, dynamic student learning should also be accompanied by developing a more genuine learning model based on a clear scientific domain (Kurnia et al., 2019; Sari et al., 2017). Although learning at the primary level that is applied is thematic-integrative learning, this should not be a limitation for teachers or researchers who have expertise in learning models to innovate in developing learning models for elementary school students constantly. Thematic learning is integrated learning that uses themes to associate several subjects with a meaningful experience for students (Antari, 2015; Bakhtiar, 2018; Ningsih \& Mahyuddin, 2021). Thematic-integrative learning encourages students to learn independently and actively in seeking and acquiring that knowledge (Wahyuningsih \& Mustadi, 2016; Windarny \& Mustadi, 2019). It provides space for teachers and researchers to develop contemporary learning models and the context of situations and conditions but cannot be separated from the thematic-integrative learning corridor for elementary school students. This research aims to produce a new learning model development called APACIN, an acronym for the learning syntax Observe, Think, Analyze, Create, and Information. It is hoped that this learning model can help students in learning.

\section{METHOD}

The method used in this research is descriptive qualitative with a case study approach. Qualitative descriptive methods are used to understand a phenomenon related to the background of the research subject in depth (Moleong, 2018). The use of descriptive qualitative is adjusted to the object of research and the purpose is carried out in a natural setting without any intervention from the researcher (Sugiyono, 2018). The scope of this research is to question the development of a learning model for elementary school students. The data sources used in this educational research are using various variations, which include learning events for elementary school students, library data sources from the study of references both books and relevant journal articles, and the results of interviews with resource persons who have the expertise and are by this research program.

\section{RESULT AND DISCUSSION}

\section{Result}

Learning activities for students refer to the Higher Order Thinking Skills (HOTS) level, which in Indonesian is known as high-order thinking skills is one approach in learning where students are taught to think critically, logically, reflectively, metacognitively, and think creatively (Suratmi et al., 2020; Widana, 2017; Yusuf et al., 2021). Higher Order Thinking Skills (HOTS) are involved in creating new knowledge. New knowledge is formed through critical and creative thinking processes in solving a problem. HOTS is expected to provide simulations to students to stimulate students' knowledge to find an idea in solving problems (Fanani, 2018; Narayanan \& Adithan, 2015). However, in this increasingly dynamic era of education, students are not enough to find problems and solve them, but there must be critical, creative, innovative action and transfer scientific knowledge to newer situations.

APACIN Learning Model is an acronym for Observe, Think, Analyze, Create, Information. This is a concrete step so that students can produce valid explanations, decisions, performances, and products in the 
context of available knowledge and experience and bridge the continuous growth of knowledge in these and other intellectual skills (Alismail \& McGuire, 2015; Wulandari, 2020). The APACIN learning model does not mean to override Bloom's Taxonomy about the analyze (analyze/C-4), evaluate (Evaluate/C-5), and Create (Create/C-6) levels, but in this case, the APACIN learning model represents things that students must do in their integrative thematic learning. Therefore, a learning model for students should be dynamic and can be developed according to the context of the situation, conditions, and civilization. One of the efforts that can be done is applying the APACIN learning model for students.

The syntax for implementing the APACIN learning model for students is as follows. First, observe. The observation process is an effort made by students to see, observe and identify things that they can see or feel. The observation process can be done using the five senses (sight, smell, taste, touch, and hearing). It can be done by observing natural phenomena or phenomena around students. Second, Think. This process refers to students' activities to process their ideas and ideas in the brain to produce statements that are by the context or can give birth to questions that arise from the results of their observations. In this phase, students should ideally be given an illustration tool to help them describe what they think. Third, analysis, where students can work in groups to conduct discussions to analyze natural phenomena or events around students. This analysis process is a process for thinking coherently that can be done to answer the questions of what, why, and how. Fourth, Copyright, this process provides students opportunities to create problemsolving ideas or alternative solutions that group members can accept. The creation of this idea is a logical and genuine idea from students because it is based on their reasoning, which group members have validated. Fifth, Information is the stage for students to show their abilities to give presentations of their creations, which can then be communicated with other students as acceptable ideas. It is also hoped that the presentation of this idea will serve as a material consideration for students or other groups to be able to respond and be given suggestions or criticisms that are relevant to the problems discussed.

\section{Discussion}

The implementation of the APACIN learning model must also involve the teacher contextually. Teachers can work together and optimize the potential of individual students and students in groups. Contextual learning prioritizes knowledge and experience or the real world, high-level thinking, studentcentered, active students, critical, creative, problem solving, students learning fun, fun, not boring, and using various learning resources (Fayakun \& Joko, 2015; Herliana \& Anugraheni, 2020; Pasaribu \& Saparini, 2017). Teachers can interact and direct in groups of medium students or large students to apply this APACIN learning model. Teachers must also have a solid initial foundation that the application of this learning model will not be separated from the concepts of critical thinking, creative thinking, reflective, and decision making aspects as the basis for implementing the APACIN model for students (McCormick et al., 2015; Mutakinati \& Anwari, 2018; Nugroho et al., 2018). It means that this learning model can be accounted for and is by the signs for the implementation of learning for students. Learning practices using the APACIN learning model can be done, one of which is learning to write poetry based on events and phenomena around students studied thematically and integrated with Natural Sciences and Civics. First, the teacher introduces and illustrates to students about the natural phenomenon of rain (by showing a series of pictures). Students are asked to observe the pictures and illustrations of seawater that evaporates upwards into cloudy clouds, which will become rain when shifted towards the mainland. Learning media can make it easier for students to understand learning material (Atsani, 2020; Febriani, 2017; Indrianto \& Kurniawati, 2020).

Second, students can think critically about the phenomenon of rain and the consequences with light, medium, to heavy intensity. Third, students are asked to identify and analyze the causes and effects caused by rain, that if it rains with low and moderate intensity, it will fertilize the soil and plants, whereas if it rains heavily, it can trigger flooding. Students can also analyze whether this flood was due to heavy rain or other factors such as scattered garbage and deforestation. At this stage, the teacher can guide students to communicate individually or in groups to conclude the three points that have been made previously. Teachers' guidance will help students learn (Hasfira \& Marelda, 2021; Palunga \& Marzuki, 2017; Wahyono et al., 2020). At this stage of analyzing, it can also shape students' character, not only can build critical and creative thinking, but also think reflectively and make decisions. Fourth, students can start creating a work of poetry that can contain rainwater, the causes of rain, to the effects caused by rain and littering. Students must actively convey their ideas and ideas so that they can be poured into writing which eventually becomes poetry. The teacher must also emphasize that one of the intrinsic elements of a poem is the existence of a moral message or message that is conveyed to other parties as lesson material. Fifth, the results of joint discussions with their respective groups that have been produced are then informed to other students to be considered and listened to and given feedback. The courage to present the results of his work is also a good point for students' academic development. The application of the APACIN learning model, which is 
presented orally and in writing to have fun, can improve critical, creative, reflective thinking and decisionmaking. Teachers who create creative learning can improve the learning atmosphere (Arfani \& Sulistia, 2019; Falloon, 2020; Timmermans et al., 2019). It can be seen from their learning outcomes which are influenced by high levels of critical and creative thinking, with an average of achieving learning demands with predetermined completeness. Students actively learning will improve students' critical thinking skills (Mahmuzah, 2015; Negor et al., 2018; Suparni, 2016).

The advantages of the APACIN learning model (Observe, Think, Analyze, Create, Information) are as follows. First, the development of the APACIN learning model refers to the curriculum and the realm of Bloom's taxonomy by the conception of education for students. Second, this learning model was developed contextually and in tandem with thematic-integrative learning for students. Third, this learning model is a product of developing a structured model that can optimize the ability of students individually and in groups. Fourth, this learning model allows teachers to optimize students' cognitive, affective, and psychomotor abilities. Fifth, students can provide contextual problem analysis and train themselves to be skilled in presenting new ideas and ideas in implementing learning in the classroom and outside the classroom. It also proves the ideal of an education system where what is learned can be implemented outside the classroom and in society (Norberg et al., 2011).

\section{CONCLUSION}

The APACIN learning model (Observe, Think, Analyze, Create, Information) can provide flexibility for students both individually and in groups to optimize their competencies and convey ideas and ideas to analyze problems, work together to solve problems, produce creative and innovative solutions, and able to present alternative solutions and the resulting innovations.

\section{REFERENCES}

Alismail, H. A., \& McGuire, P. (2015). 21 St Century Standards and Curriculum: Current Research and Practice. Journal of Education and Practice, 6(6).

Anggreni, Wiarta, \& Putra. (2020). Pengaruh Model Pembelajaran ( SAVI ) Berbasis ( TIK ) Terhadap Kompetensi Pengetahuan Matematika. Pedagogi Dan Pembelajaran, 3(1), 15-24. https://doi.org/10.23887/jp2.v3i1.24357.

Antari, L. (2015). Penggunaan Bahan Ajar Tematik Pembagian Untuk Meningkatkan Hasil Belajar Di Kelas Iia Mi Ahliyah Ii Palembang. AKSIOMA Journal of Mathematics Education, 4(2), 22-29. https://doi.org/10.24127/ajpm.v4i2.307.

Arfani, S., \& Sulistia, A. (2019). Teaching Speaking Using A “Snake And Ladder" Board Game: A Teacher Story. Research and Innovation in Language Learning, 2(1). https: //doi.org/10.33603/rill.v2i1.1642.

Arisantiani, N. K., Putra, M., \& Ganing, N. N. (2017). Pengaruh Model Pembelajaran Childrens Learning In Science (Clis) Berbantuan Media Lingkungan Terhadap Kompetensi Pengetahuan IPA. Journal of Education Technology, 1(1). https://doi.org/10.23887/jet.v1i2.11774.

Arthaningsih, N. K. J., \& Diputra, K. S. (2018). Pengaruh Model Pembelajaran Kooperatif Tipe Two Stay Two Stray melalui Lesson Study terhadap Hasil Belajar Matematika. Journal of Education Technology, 2(4), 128-136. https://doi.org/10.23887/jet.v2i4.16424.

Atsani, K. L. (2020). Transformasi Media Pembelajaran Pada Masa Pandemi Covid-19. Jurnal Teknologi Pendidikan, 22(1), 65-70. https://doi.org/10.47730/jurnallampuhyang.v11i2.194.

Ayuni, I. A. S., Kusmariyatni, N., \& Japa, I. G. N. (2017). Pengaruh Model Pembelajaran Talking Stick Berbantuan Media Question Box Terhadap Hasil Belajar IPA Kelas V. Journal of Education Technology, 3(1). https://doi.org/10.23887/jet.v1i3.12503.

Bahtiar, R. S. (2019). Efektivitas Penggunaan Media Papan Waktu Pada Pembelajaran Penghitungan Waktu Bagi Siswa Kelas Iii Sekolah Dasar. Jurnal Bidang Pendidikan Dasar, 3(1), 14-23. https://doi.org/10.21067/jbpd.v3i1.2857.

Bakhtiar, F. A. (2018). Pengembangan Aplikasi Berbasis Multimedia pada Pembelajaran Tematik Kelas III Sekolah Dasar. Mimbar Sekolah Dasar, 5(1), 16. https://doi.org/10.17509/mimbar-sd.v5i1.9363.

Daunic, A. P., Corbett, N. L., Smith, S. W., Algina, J., \& Poling, D. (2021). Efficacy of the social-emotional learning foundations curriculum for kindergarten and first grade students at risk for emotional and behavioral disorders. Journal of School Psychology, 86. https://doi.org/10.1016/j.jsp.2021.03.004.

Dewi, N. N. K., Kristiantari, M. . R., \& Ganing, N. N. (2019). Pengaruh Model Pembelajaran Picture And Picture Berbantuan Media Visual Terhadap Keterampilan Menulis Bahasa Indonesia. Journal of Education Technology, 3(4). https://doi.org/10.23887/jet.v3i4.22364. 
Dhiu, K. D. (2017). Learning Motivation And Perception Of The Teachers' Pedagogic Competence And Learning Achievement In Social Science Of Junior High School Students. Journal of Education Technology, 1(1), 6-12. https://doi.org/10.23887/jet.v1i1.10078.

Falloon, G. (2020). From digital literacy to digital competence: the teacher digital competency (TDC) framework. Educational Technology Research and Development, 68(5), 2449-2472. https://doi.org/10.1007/s11423-020-09767-4.

Fanani, M. Z. (2018). Strategi Pengembangan Soal Higher Order Thinking Skill (HOTS) dalam Kurikulum 2013. Edudeena, 2(1), 57-76. https://doi.org/10.30762/ed.v2i1.582.

Fayakun, M., \& Joko, P. (2015). Efektivitas Pembelajaran Fisika Menggunakan Model Kontekstual (Ctl) Dengan Metodepredict, Observe, Explain Terhadap Kemampuan Berpikir Tingkat Tinggi. Jurnal Pendidikan Fisika Indonesia, 11(1), 49-58. https://doi.org/10.15294/jpfi.v11i1.4003.

Febriani, C. (2017). Pengaruh Media Video terhadap Motivasi dan Hasil Belajar Kognitif Pembelajaran IPA Kelas V Sekolah Dasar. Jurnal Prima Edukasia, 5(1), 11-21. https://doi.org/10.21831/jpe.v5i1.8461.

Handayani, N. M. D., Ganing, N. N., \& Suniasih, N. W. (2017). Model Pembelajaran Picture and Picture Berbantuan Media Audio-Visual Terhadap Pengetahuan IPA. Journal of Education Technology, 1(3), 176. https://doi.org/10.23887/jet.v1i3.12502.

Hasfira, H., \& Marelda, M. (2021). Peran Guru Dalam memotivasi Siswa Pada Masa Pandemi. Jurnal Pendidikan Dan Konseling (JPDK), 3(1), 80-84. https://doi.org/10.31004/jpdk.v3i1.1430.

Herliana, S., \& Anugraheni, I. (2020). Pengembangan Media Pembelajaran Kereta Membaca Berbasis Kontekstual Learning Siswa Sekolah Dasar. Jurnal Basicedu, 4(2), 314-326. https://doi.org/10.31004/basicedu.v4i2.346.

Indrianto, N., \& Kurniawati. (2020). Developing Pop-Up Book Based Media To Improve The First Grader Students' Learning Achievement on The Theme of Natural Event of Min 4 Jember. Jurnal Pendidikan Dasar Nusantara, 5(2), 279-291. https://doi.org/10.29407/jpdn.v5i2.13836.

Kurnia, V. T., Damayani, A. T., \& Kiswoyo, K. (2019). Keefektifan Model Pembelajaran Number Head Together (NHT) Berbantu Media Puzzle Terhadap Hasil Belajar Matematika. Jurnal Ilmiah Sekolah Dasar, 3(2), 192. https://doi.org/10.23887/jisd.v3i2.17772.

Kusmariyatni, N. (2020). Media Pop-Up Book pada Topik Sistem Tata Surya Kelas VI Sekolah Dasar. Jurnal Ilmiah Sekolah Dasar, 4(2), 197-208. https://doi.org/10.23887/jisd.v4i2.25135.

Lestari, K. D., Suniasih, N. W., \& Manuaba, I. B. S. (2017). Pengaruh Model Pembelajaran Open Ended Berbasis Keterampilan Menjelaskan Terhadap Kompetensi Pengetahuan Ipa. Journal of Education Technology, 1(3), 169. https://doi.org/10.23887/jet.v1i3.12501.

Mahmuzah, R. (2015). Meningkatkan Kemampuan Berpikir Kritis Matematik Siswa Smp Melalui Pendekatan Problem Posing. Jurnal Peluang, 4(1). https://doi.org/10.35194/jp.v6i2.123.

Marliani. (2015). Peningkatan Kemampuan Berpikir Kreatif Matematis Siswa melalui Model Pembelajaran Missouri Mathematics Project (MMP). Jurnal Ilmiah Pendidikan MIPA, 5(1), 14-25. https://doi.org/10.30998/formatif.v5i1.166.

McCormick, N. J., Clark, L. M., \& Raines, J. M. (2015). Engaging Students in Critical Thinking and Problem Solving: A Brief Review of the Literature. Journal of Studies in Education, 5(2), 100-113. https://doi.org/10.5296/jse.v5i4.8249.

Moleong, L. J. (2018). Metodologi Penelitian Kualitatif. Remaja Rosdakarya.

Mutakinati, \& Anwari. (2018). Analysis Of Students ' Critical Thinking Skill Of Middle School Through Stem Education Project-Based Learning. Jurnal Pendidikan IPA Indonesia, 7(1), 54-65. https://doi.org/10.15294/jpii.v7i1.10495.

Narayanan, S., \& Adithan, M. (2015). Analysis Of Question Papers In Engineering Courses With Respect To Hots (Higher Order Thinking Skills). American Journal of Engineering Education (AJEE), 6(1), 1-10. https://doi.org/10.19030/ajee.v6i1.9247.

Negor, R. A., Hidayah, H., Subali, B., \& Rusilowati, A. (2018). Upaya Membangun Ketrampilan Berpikir Kritis Menggunakan Peta Konsep Untuk Mereduksi Miskonsepsi Fisika. JP (Jurnal Pendidikan), 3(1). https://doi.org/10.26740/jp.v3n1.p45-51.

Ningsih, S. Y., \& Mahyuddin, N. (2021). Desain E-Module Tematik Berbasis Kesantunan Berbahasa Anak Usia Dini di Taman Kanak-Kanak. Jurnal Obsesi : Jurnal Pendidikan Anak Usia Dini, 6(1), 137-149. https://doi.org/10.31004/obsesi.v6i1.1217.

Norberg, A., Dziuban, C. D., \& Moskal, P. D. (2011). A time-based blended learning model. On the Horizon, 19(3). https://doi.org/10.1108/10748121111163913.

Nugroho, P. B., Nusantara, T., As'ari, A. R., Sisworo, Hidayanto, E., \& Susiswo. (2018). Critical Thinking Disposition: Students Skeptic in Dealing with Ill-Logical Mathematics Problem. International Journal of Instruction, 11(3), 635-648. https://doi.org/10.12973/iji.2018.11343a. 
Palunga, \& Marzuki. (2017). Peran Guru Dalam Pengembangan Karakter Peserta Didik Di Sekolah Menengah Pertama Negeri 2 Depok Sleman. Jurnal Pendidikan Karakter, 1(1). https://doi.org/10.21831/jpk.v7i1.20858.

Pasaribu, A., \& Saparini. (2017). Pengembangan Bahan Ajar Berbasis Kontekstual untuk Meremidiasi Miskonsepsi pada Materi Gaya dan Hukum Newton. Jurnal Inovasi Dan Pembelajaran Fisika, 4(2), 36-47. https://doi.org/10.36706/jipf.v4i1.4264.

Permatasari, N. A., Setiawan, D., \& Kironoratri, L. (2021). Model Penanaman Karakter Disiplin Siswa Sekolah Dasar pada Masa Pembelajaran Daring. Educatif: Jurnal Ilmu Pendidikan, 3(6), 3758-3768. https://doi.org/10.31004/edukatif.v3i6.1303.

Pramana, I. P. Y., \& Suarjana, I. M. (2019). Pengaruh Model Pembelajaran Time Token Berbantuan Media Video Terhadap Hasil Belajar IPA Kelas V SD. Journal of Education Technology, 2(4), 137. https://doi.org/10.23887/jet.v2i4.16425.

Prayekti. (2018). The Influence of Cognitive Learning Style and Learning Independence on the Students' Learning Outcomes. Higher Education Studies, 8(2), 37. https://doi.org/10.5539/hes.v8n2p37.

Santiasih, N. I., Marhaeni, A. A. I. N., \& Tika, I. N. (2013). Pengaruh Model Pembelajaran Inkuiri Terbimbing Terhadap Sikap Ilmiah dan Hasil Belajar IPA Siswa Kelas V SD No. 1 Kerobokan Kecamatan Kuta Utara Kabupaten Badung Tahun Pelajaran 2013/2014. Jurnal Pendidikan Dasar Ganesha, 3(1). https://doi.org/10.23887/jet.v3i1.17959 Article Metrics.

Sari, R. Y., Netriwati, N., \& Sari, F. I. (2017). Pengaruh Model Pembelajaran Attention, Relevance, Confidence and Satisfaction (ARCS) terhadap Kemampuan Berpikir Matematis berdasarkan Taksonomi Bloom Revisi. Numerical: Jurnal Matematika Dan Pendidikan Matematika, 1(1). https://doi.org/10.25217/numerical.v1i1.119.

Seika Ayuni, I. G. a. P. A., Kusmariyatni, N., \& Japa, I. G. N. (2017). Pengaruh Model Pembelajaran Talking Stick Berbantuan Media Question Box Terhadap Hasil Belajar Ipa Kelas V. Journal of Education Technology, 1(3), 183. https://doi.org/10.23887/jet.v1i3.12503.

Septianti, N., \& Afiani, R. (2020). Pentingnya Memahami Karakteristik Siswa Sekolah Dasar di SDN Cikokol 2. As-Sabiqun, 2(1), 7-17. https://doi.org/10.36088/assabiqun.v2i1.611.

Setianingsih, I. G. A. A. A., Putra, D. K. N. S., \& Kt.Ardana, I. (2019). Pengaruh Model Pembelajaran Reciprocal Teaching Berbantuan Media Audio Visualterhadap Kompetensi Pengetahuan IPA. Journal of Education Technology, 3(3), 203-209. https://doi.org/10.23887/jet.v3i3.21827.

Sugiyono. (2018). Metode Penelitian Pendidikan Pendekatan Kuantitatif, Kualitatif dan R\&D. Alfa Beta.

Suherti, H., \& Tsuroya, T. F. (2019). Implementasi Model Cooperative Learning Teknik Stad Untuk Meningkatkan Kemampuan Berpikir Kreatif Mengajar dalam Program Latihan Profesi. Jurnal Soshum Insentif, 2(1), 67-79. https://doi.org/10.36787/jsi.v2i1.49.

Suparni. (2016). Upaya Meningkatkan Kemampuan Berpikir Kritis Mahasiswa Menggunakan Bahan Ajar Berbasis Integrasi Interkoneksi. Jurnal Derivat: Jurnal Matematika Dan Pendidikan Matematika, 3(2). https://doi.org/10.31316/j.derivat.v3i2.716.

Suratmi, Laihat, \& Asnimar. (2020). Development of Assessment Instruments Based on Higher Order Thinking Skills (HOTS) for Elementary School Students. Jurnal Pendidikan Sekolah Dasar (JPsd), 6(1), 199-211. https://doi.org/10.30870/jpsd.v6i2.7356.

Sutrisno, Zar'in, F., \& Salehcah, S. (2021). Local Content Curriculum Model for Early Childhood Scientific Learning. Jurnal Pendidikan Usia Dini, 15(1). https://doi.org/10.21009/JPUD.151.05.

Timmermans, A. C., Werf, M. P. C. G. van der, \& Rubie-Davies, C. M. (2019). The interpersonal character of teacher expectations: The perceived teacher-student relationship as an antecedent of teachers' $\begin{array}{lllll}\text { track recommendations. Journal of } & 73 .\end{array}$ https://doi.org/10.1016/j.jsp.2019.02.004.

Wahyono, P., Husamah, H., \& Budi, A. S. (2020). Guru profesional di masa pandemi COVID-19: Review implementasi, tantangan, dan solusi pembelajaran daring. Jurnal Pendidikan Profesi Guru, 1(1), 5165. https://doi.org/10.22219/jppg.v1i1.12462.

Wahyuningsih, E., \& Mustadi, A. (2016). Pengembangan multimedia lectora pembelajaran tematik-integratif untuk peningkatan nilai karakter siswa kelas iv sekolah dasar. Jurnal Pendidikan Karakter, 1(1). https://doi.org/10.21831/jpk.v0i1.10729.

Widana, I. W. (2017). Higher Order Thinking Skills Assessment (HOTS). JISAE (Journal of Indonesian Student Assessment and Evaluation), 3(1), 32-44. https://doi.org/10.21009/JISAE.031.04.

Widani, N. K. T., Sudana, D. N., \& Agustiana, I. G. A. T. (2019). Pengaruh Model Pembelajaran Inkuiri Terbimbing Terhadap Hasil Belajar IPA Dan Sikap Ilmiah Pada Siswa Kelas V SD Gugus I Kecamatan Nusa Penida. Journal of Education Technology, 3(1), 15-21. https://doi.org/10.23887/jet.v3i1.17959.

Widodo. (2014). Strategi Peningkatan Aktivitas Jasmani Siswa Sekolah Dasar di Luar Pembelajaran 
Pendidikan Jasmani, Olahraga, dan Kesehatan di Indonesia. Jurnal Pendidikan Dan Kebudayaan, 20(2), 281-294. https://doi.org/10.24832/jpnk.v20i2.144.

Windarny, D., \& Mustadi, A. (2019). Pengembangan Lectora Dalam Pembelajaran Tematik-Integratif Untuk Peningkatan Prestasi Belajar Kognitif Dan Karakter Siswa Sekolah Dasar. Jurnal Pendidikan Karakter, 1(1). https://doi.org/10.21831/jpk.v8i2.21851.

Wulandari, I. G. A. A. (2020). Implementation of the 2013 Curriculum Based on a Scientific Approach (Case Study at SD Cluster II Kintamani). International Journal of Elementary Education, 4(3), 422-430. https://doi.org/10.23887/ijee.v4i3.28172.

Yusuf, I., Widyaningsih, S. W., Prasetyo, Z. K., \& Istiyono, E. (2021). Blended learning : its effect towards Higher Order Thinking Skills ( HOTS ) Blended learning : its effect towards Higher Order Thinking Skills ( HOTS ). Journal of Physics: Conference Series, 1832(1), 1-10. https://doi.org/10.1088/17426596/1832/1/012039.

Zeptyani, \& Wiarta. (2020). Pengaruh Project-Based Outdoor Learning Activity Menggunakan Media Audio Visual Terhadap Perilaku Belajar Anak Usia Dini. Jurnal Pendidikan Anak Usia Dini Undiksha, 8(2), 69-79. https://doi.org/10.23887/paud.v8i2.24740. 